\title{
A correlation between self concept and procrastination based on gender in neuroscience perspective
}

\author{
Yussa Annisa Syabilla, Ade Suryanda*, Diana Vivanti Sigit \\ Biology Education, Faculty of Mathematics and Natural Science, Universitas Negeri Jakarta \\ *Corresponding author: asuryanda@unj.ac.id
}

\section{A R T I C L E I N F O}

Article history:

Received 7 September 2018

Revised 25 October 2018

Accepted 29 October 2018

Keywords:

Neuroscience,

procrastination, self concept

\begin{abstract}
A B S T R A C T
One of the responsibilities of students is to work on academic tasks in a disciplined manner. The problem that arises is when students have a tendency to delay their academic assignments. This is called academic procrastination. Academic procrastination is procrastinating behavior in carrying out academic assignments. One of the internal factors that is important to study related to procrastination is academic self-concept. Selfconcept becomes a personality style that is important to be explored further in research on procrastination because a person tends to act in line with the self-concept possessed. There have been many studies conducted related to procrastination. Internal factors of academic procrastination aside from psychological factors also have physiological factors such as neuro activity. This research was conducted at SMAN 44 Jakarta in April-May 2018. The research method used was quantitative descriptive method. The sample used is 120 XI MIPA students. Based on the calculation results obtained normal and homogeneous distributed data. The result of hypothesis testing shows that academic self concept has negative correlation with academic procrastination and rxy is -0473. The academic self concept has a contribution of $22.4 \%$ in determining the academic procrastination of learners on Biology subjects. This research implies that the importance of improving students 'academic self-concept, especially for teachers, is expected to be able to do Biology learning with methods that can develop students' academic self-concept.
\end{abstract}

(C) 2018 Universitas Negeri Jakarta. This is an open access article under the CC-BY license (https://creativecommons.org/licenses/by/4.0)

\section{INTRODUCTION}

Senior High School is one level of formal education that aims to prepare students towards education in Higher Education (Bintaraningtyas, 2015; Ristanto, 2009). Each school certainly has a desire to form disciplined students and can do academic tasks that are given well so that students 
are expected to gain success in learning. Success in learning will not be separated from the behavior of students in learning.

Learning behavior in students is so diverse. Good learning behavior will arise when students are aware of their responsibilities as students. The responsibility of students in school is one of which is to carry out well the tasks that the teacher gives. However, students have a tendency to procrastinate in completing the assignments given to them. Students tend to postpone what can be done at that time for various reasons so that the time they have is not managed properly (Bintaraningtyas, 2015). This phenomenon of procrastination in psychological terms is known as procrastination. Meanwhile, the habit of procrastinating, especially in completing academic assignments, is called academic procrastination.

Academic procrastination can occur in various academic fields, one of them is in Biology. So diverse are the tasks that can be given to Biology subjects ranging from the task of writing practicum reports, reading Biology material, making mind maps, to drawing things related to biological material. This causes the tendency of students to procrastinate on Biology subjects as well.

Procrastination is important to study because of the high frequency of procrastination (Solomon \& Rothblum, 1984; Steel, 2007; Surijah, 2007). Klassen \& Kuzucu (2009) found that more than $40 \%$ of Turkish teenagers spent three to hours delaying assignments during school days. Besides having a high frequency procrastination gives a lot of harm to the perpetrators, both material and immaterial losses (Steel, 2007). According to Ferrari \& Morales (2007) academic procrastination has a negative impact, namely the amount of time wasted without producing anything useful.

Gender differences in frequency of procrastination has been one of the most discussed issue due to inconsistent research findings. Some studies have failed to find gender differences in procrastination (e.g. Hess, Sherman, \& Goodman, 2000; Şirin, 2011; Balkis, et al., 2017). Some authors have argued that females are greater risk for procrastination (e.g. Doyle \& Paludi, 1998, Washington, 2004). The other group researcher reported that males are greater risk for procrastination (e.g. Özer et al., 2009; Steel, 2007; Steel \& Ferrari, 2013). For instance, in a re- cent study with large sample conducted by Steel \& Ferrari (2013) confirmed that males more likely to procrastinate than females.

There have been many studies conducted related to procrastination. Internal factors of academic procrastination aside from psychological factors also have physiological factors. Physiologically, a person's behavior, including procrastination, is influenced by neural activity (neurobiological). Research conducted by Rabin (2011) shows that in terms of neurobiology, academic procrastination is controlled by frontal lobe activity. The frontal area of the brain, involved in what is known as 'executive function', in the induction of procrastination. This brain activity is also influenced by an impulsive system known as the amygdala. Amygdala is involved in the neurobiology of procrastination because it also plays a role in building what is known as a 'fight or flight' response. This physiological reaction can explain how a person can tend to avoid the task and delay the tasks that have been given to him that are also related to the work of the adrenal hormones and dopamine neurotransmitters.

Another problems or factors that influence procrastination (Davis \& Abbitt, 2013). For example, research conducted by Emadian \& Pasha (2016) mentions that one of the internal contributors is academic procrastination, namely self concept and attachment style. Academic selfconcept is the perception of a student towards the academic abilities that he has formed through experience and interaction with the environment. Academic self-concept is one of the most relevant variables in the academic world because of its influence on learning and cognitive function (Villegas, et al., 2013). Academic self-concept is also important in shaping a person's behavior in academic terms, including one of the behaviors of academic procrastination.

Students who have a negative self-concept will have an assessment or negative perception about themselves. These negative perceptions lead to one of the low self-confidence of students towards him. Not confident means expression to mean the statement of students' inability to do 
something. Students think and judge negatively themselves so that feelings of unpleasantness and encouragement or tendency to avoid what they will do. And this can lead to delays in students doing academic tasks known as academic procrastination.

The importance of self-concept in influencing a person's actions makes it a worthy factor to be studied in relation to the acts of procrastination behavior carried out by students. Therefore, this study aims to determine the relationship between self-concept and procrastination based on Gender in neuroscience perspective.

\section{METHOD}

This research is a descriptive correlation study. The independent variables used are academic self-concept while the dependent variable is academic procrastination. The target population in this study were all students of SMAN 44 Jakarta. While the affordable population in this study are students of class XI Science at SMAN 44 Jakarta.This research uses Simple Random Sampling sampling technique, by choosing students randomly from the population. Determination of the number of samples from certain populations was developed from the Taro Yamane formula and obtained 120 samples from 144 students. The research is carried out in the even semester of 2017/2018 school year. Retrieval of academic self-concept data with instruments of academic selfconcept and academic procrastination with instruments of academic procrastination. Procrastination instrument consists of three dimensions, namely delaying, avoiding tasks, and blaming others. Data obtained from research instruments were analyzed with SPSS for windows through several stages, namely: 1) normality test with Kolmogorov-Smirnov test and Bartlett homogeneity test, and 2) hypothesis testing by testing the regression model, linearity test, and Pearson correlation technique. Pearson correlation analysis is used to determine whether there is a relationship between academic self-concept behavior and academic procrastination. This study hypothesizes that there is a negative relationship between academic self-concept and academic procrastination.

\section{RESULT AND DISCUSSION}

Correlation test results to determine the relationship between academic self-concept and academic procrastination are shown in Table 1 .

Table 1. Results of Academic Self-Correlation Test Results with Academic Procrastination.

\begin{tabular}{llrr}
\hline & & $\begin{array}{r}\text { Academic Self } \\
\text { Concept }\end{array}$ & Academic Procrastination \\
\hline Academic Self & Pearson & 1 & $-.473^{* *}$ \\
Concept & Correlation & & .000 \\
& Sig. (2-tailed) & 120 & 120 \\
\hline N & Pearson &,$- 473^{* *}$ & 1 \\
\hline Academic & Correlation & .000 & \\
Procrastination & Sig. (2-tailed) & 120 & 120 \\
& N & & \\
& &
\end{tabular}

Based on the results in Table 1, it is stated that there is a significant negative relationship between academic self-concept and academic procrastination. 
Table 2. Composition of values in gender academic procrastination.

\begin{tabular}{lrrrrr}
\hline $\begin{array}{c}\text { Categor } \\
\mathbf{y}\end{array}$ & $\begin{array}{r}\text { Number of Female } \\
(\mathbf{F})\end{array}$ & $\begin{array}{r}\text { Percenta } \\
\text { ge (\%) }\end{array}$ & $\begin{array}{r}\text { Number of } \\
\text { Male (M) }\end{array}$ & $\begin{array}{r}\text { Percentage } \\
(\mathbf{\%})\end{array}$ & Total of Percentage \\
\hline Low & 14 & 11,67 & 9 & 7,5 & 19.17 \\
Medium & 37 & 30,83 & 45 & 37,75 & 68.58 \\
High & 2 & 1,67 & 13 & 10,83 & 12.5 \\
\hline Total & 53 & 44 & 67 & 56 & 100 \\
\hline
\end{tabular}

Table 2 is the result of the categorization of academic procrastination which shows that most of the students are in the medium category with the percentage of academic procrastination scores for male students higher than female.

Tabel 3. Composition of values in gender academic self concept.

\begin{tabular}{lrrrrr}
\hline Category & $\begin{array}{r}\text { Number of } \\
\text { Female } \\
(\mathbf{F})\end{array}$ & $\begin{array}{r}\text { Percentage } \\
(\mathbf{\%})\end{array}$ & $\begin{array}{r}\text { Number of } \\
\text { Male (M) }\end{array}$ & $\begin{array}{r}\text { Percentage } \\
(\mathbf{\%})\end{array}$ & Total of Percentage \\
\hline Low & 8 & 6,67 & 10 & 8,33 & 15 \\
Medium & 35 & 29,17 & 43 & 35,83 & 65 \\
High & 10 & 8,33 & 14 & 11,67 & 20 \\
\hline Total & 53 & 44 & 67 & 56 & 100 \\
\hline
\end{tabular}

Table 3 is the result of categorizing academic self-concept which shows that most students are in the medium category.

This study found that there was a negative relationship between academic self-concept and academic procrastination of students in Biology subjects. The coefficient obtained is equal to -0.473 which means there is moderate enrichment. This means that academic self-concept with academic procrastination have enough connection. The results of this study are in accordance with the results of research by Pasha (2016) \& Ferrari (2007) which states that there is a negative relationship between academic self-concept and academic procrastination. Negative relationships from the results of this study indicate that the higher the number of students who are educated the lower the academic procrastination conducted by students.

Students with low self-concept tend to be pessimistic about their competencies in learning. So that the tasks received are not immediately resolved but seek other activities so that it can be said that self-concept is an important determinant of students' responses to the environment. If the students' self-concept is high, their learning activities will be influenced positively. Conversely, if the students' self-concept is low, their learning behavior will be influenced negatively. This is in line with previous studies by Hamachek in Abdillah (2011) stating that a positive or high academic self concept will improve students' academic performance to be better and minimize the emergence of learning difficulties in students.

Study shows there are some students who have high self-concept with a low level of procrastination and some students who have low self-concept with a high level of procrastination while there are no students who have high self-concept with a high level of procrastination. This shows that there is a negative relationship between academic self-concept and academic procrastination so that it can be said that a high self-concept makes students not just doing academic procrastination so that the level of procrastination is low and vice versa. Students with high self-concept have characteristics, one of which is being able to overcome difficulties or problems they have. This makes students consider themselves able to do academic tasks that they have and also does not give up on difficulties in their tasks and always do the tasks with enthusiasm and optimism so that the task can be completed properly and on time or in other words the students tend not to perform academic procrastination. This shows that most students who have academic self-concept also perform academic procrastination in the medium category. This is supported by previous research by Goodvin et al., (2008) which states that academic self-concept can affect how 
diligent students are in performing difficult tasks. Good academic concepts for participants who do not allow to neglect their duties or in this case academic procrastination.

Based on the results obtained in this study, students of SMAN 44 Jakarta have the most selfconcept of academic in the medium category, which means that most have a concept above average. The results of the calculation of the composition of academic self-concept based on gender show that between the self-concept of female and male students does not show a real difference. Each has a moderate percentage of self concept with the most number and a low and high percentage of self concept with a small amount. This shows that in this study, gender does not determine the high and low self-concept of students. According to Setiawan (2008) there are three things that affect selfconcept, namely age, social environment, and competence.

The results of the calculation of academic procrastination in the Biology subject of students of SMAN 44 Jakarta showed that most of the students had the value of procrastination in the medium category and there were a small number who had the value of procrastination in the high category. This means that some students still often postpone their Biology assignments or learn to test Biology materials, improve the Biology tasks that should be completed, or choose to do other activities that are more enjoyable so that the Biology tasks are improved.

The results of the calculation of the composition of the academic procrastination based on gender show that between procrastination owned by female and male students there is a difference. The percentage shows that male students have higher procrastination than female students. This shows that in this study, gender determines the level of procrastination that students have.

A study conducted by Brownlow \& Reasinger (2000) reveals procrastination related to gender, that men who are often extrinsically motivated and dissatisfied with a given task are more likely to delay compared to women. Despite the fact that women also delay with reasons such as the need to produce perfect work (perfectionism) and thus delay starting the task given in an effort to protect their academic abilities if the results are unpleasant, women still delay lower than men.

The results showed that academic self-concept contributed $22.4 \%$ to academic procrastination, while the remaining $77.6 \%$ could be influenced by other factors. This shows that academic self-concept is not the only factor that determines the level of academic procrastination. There have been many studies conducted related to procrastination. Internal factors of academic procrastination aside from psychological factors also have physiological factors such as neuro activity. Research conducted by Rabin (2011) shows that in terms of neurobiology, academic procrastination is controlled by frontal lobe activity. The frontal area of the brain, involved in what is known as 'executive function', in the induction of procrastination. Executive function is a term that encompasses a number of different processes, including problem solving, changing actions in response to new information, planning strategies and completing complex tasks and most importantly managing one's control of one's emotions, behavior, and cognitive abilities. In addition, this study highlights that procrastination can occur due to front brain dysfunction.

Another research show that by examining 20 brains (11 female, 9 male) approximately $18 \%$ more nerve cells into areas of the prefrontal lobes; the prefrontal lobes help regulate higher functions such as language, judgment, and planning future actions. Although women start out with more cells in these areas, by old age, men and women have similar number of cells in the frontal lobes. This is because women lose cells in these areas faster as they age than men do. This may contribute to the higher incidence of Alzheimer's disease in women (Wittleson, 2001).

According to Rabin (2011) one of the impulsive systems that achieve function of the prefrontal cortex is the amygdala. Amygdala is a brain region that has been equipped with mediation of a variety of normal functions including courage, memory, and decision making and is also involved in a variety of psychological problems and anxiety. The Amygdala is involved in the neurobiology of procrastination because of its role in building what is known as a 'fight or flight' response. This physiological reaction can explain how a person can perform tasks and postpone tasks that have been given real.

When students carry out their activities with highly challenging activities such as the school exam office, or by spending various activities carried out, make conclusions that involve 
emotionally as a 'flight' in an effort to protect from feelings of panic, depression or negative selfdoubt. Thats how a student starts panicking about how much to do before tomorrow's exam, it is for the hormones that are secreted by adrenaline. Adrenaline can generate a response from the area involved in logistics planning and reasoning, which is the pre-frontal part that has been lit before. Next, someone will carry out activities as a short-term call such as a TV program for several hours even though an individual knows that there are deadlines that must be worked on for tomorrow. This short-term separation can instantly make a person relax and improve mood with the production of a dopamine neurotransmitter. Dopamine produced by the brain when a person is engaged in a fun activity to be used by individuals who will continue to work with others to choose others and individuals who become procrastinators. This is supported by Steel's (2007) research which states that fun activities will be an option for people who give satisfaction to people involved in certain jobs or activities to do procrastination.

\section{CONCLUSION}

Based on the results of the study it can be concluded that there is a negative relationship between self-concept and procrastination of students in the academic field in the subject of Biology at SMAN 44 Jakarta so that it can be said that if the students' self-concept is low then academic procrastination is high so vice versa. There needs to be an in-depth study related to learning methods that can improve students' academic self-concept.

\section{Suggestion}

Based on the conclusions, the advice that needs to be considered for future research is to conduct an in-depth study of procrastination with other physiological factors such as genetic and neurological aspects through neuroscience studies. An experimental research is also needed in learning that can develop students' academic self-concept, especially in Biology subjects.

\section{REFERENCES}

Abdillah, R. (2011). Difference between academic self concepts between international students budi mulia dua yogyakarta and diponegoro vocational high school yogyakarta, (Thesis unpublished), Faculty of Social Sciences \& Humanities, Psychology Study Program, Sunan Kalijaga State Islamic University Yogyakarta, Yogyakarta.

Balkis, M., Duru, E., \& Bulus, M. (2017). Gender differences in the relationship between academic procrastination, satifaction with academic life and academic performance. Electronic Journal of Research in Educational Psychology, 15(1), 105-125.

Bintaraningtyas, N. (2015). Hubungan antara kontrol diri dengan prokrastinasi akademik pada siswa sma, (Thesis unpublish), Universitas Muhammadiyah Surakarta, Surakarta.

Davis, D. R. \& Abbitt, J. T. (2013). An investigation of the impact of an intervention to reduce academic procrastination using short message service (SMS) technology. Journal of Interactive Online Learning, 12(3), 78-102.

Doyle J. A. \& Paludi M. A. (1998). Sex and gender: The human experience (4th ed.). San Francisco: McGraw- Hill.

Emadian, S. O. N., \& Firoz, Z. P. (2016). The relationship between attachment style, self-concept and academic procrastination. International Academic Journal of Humanities, 3(5), 1-7.

Ferrari, J. R. \& Morales, J. F. D. (2007). Perceptions of Self-concept and Self- presentation by Procrastinators: Further Evidence. Chicago. The Spanish Journal of Psychology, 10(1), 9-16.

Hess, B., Sherman, M. F., \& Goodman, M. (2000). Eveningness predicts academic procrastination: the mediating role of Neuroticism. Journal of Social Behavior and Personality, 15, 61- 
74.

Klassen, R. M., \& Kuzucu, E. (2009). Academic procrastination and motivation of adolescents in Turkey. Educational Psychology, 29 (1), 69-81.

Özer, B.U., Demir, A., \& Ferrari, J. (2009) Exploring academic procrastination among Turkish students: Possible gender differences in prevalence and reasons. The Journal of Social Psychology, 149(2), 241-257. http://dx.doi.org/ 10.3200/SOCP.149.2.241-257.

Rabin, L.A., Fogel, J., \& Nutter-Upham, K.E. (2011). Academic procrastination in college students: The role of self-reported executive function. Journal of Clinical and Experimental Neuropsychology, 33, 344-357.

Ristanto, R. H. (2009). Implementasi model pembelajaran kooperatif tipe circ cooperative integrated reading and composition) untuk meningkatkan hasil belajar biologi kelas xi ipa $i$ "topik gangguan sistem transportasi pada manusia "sma negeri 1 sambungmacan, sragen tahun ajaran 2008/2009, (Unpublish Thesis), Universitas Muhammadiyah Surakarta, Surakarta.

Şirin, E. F. (2011). Academic procrastination among undergraduates attending school of physical education and sports: Role of general procrastination, academic motivation and academic self-efficacy. Educational Research \& Review, 5, 447-465.

Steel, P. (2007). The nature of procrastination: a metaanalytic and theoretical review of the quintessentialn self regulation failure. Psychological bulletin, 133 (1), 65-94.

Steel, P., \& Ferrari, J. (2013). Sex, education and procrastination: An epidemiological study of procrastinators' characteristics from a global sample. European Journal of Personality, 27, 51-58. http://dx.doi.org/10.1002/per.1851.

Steel, P. (2007). The nature of procrastination: A meta-analytic and theoretical review of quintessential self-regulatory failure. Psychological Bulletin, 133, 65-94. http://dx.doi.org/10.1037/0033-2909.133.1.65.

Surijah, E. A \& Sia, T. (2007). Students Versus Tasks: Academic Procrastination and Conscientiousness. ANIMA Indonesian Psychological Journal, 22(4), 352-374.

Villegas, G., Tomasini., Guadalupe., \& Isabel, R. L. (2013). Development of an academic self concept for adolescents (ASCA) scale. Journal of Behavior, Health \& Social Issues, 5, $117-$ 13.

Washington, J.A. (2004). The relationship between procrastination and depression among graduate and professional students across academic programs: Implications for counseling. (Doctoral Dissertation). Retrieved from ProQuest Dissertations and Theses (Accession Order No. AAT 3155848).

Witelson, S.F., Kigar, D.L. \& Stoner-Beresh, H.J. (2001). Sex difference in the numerical density of neurons in the pyramidal layers of human prefrontal cortex: a stereologic study. Paper presented to the annual Society for Neuroscience meeting in San Diego, US. 